BNL-98372-2012

\title{
The Indian Advanced Heavy Water Reactor (AHWR) and Non-Proliferation Attributes
}

\author{
M. Todosow, A. Aronson, L.-Y. Cheng \\ Brookhaven National Laboratory \\ R. Wigeland \\ Idaho Natioanl Laboratory
}

C. Bathke, C. Murphy, B. Boyer, J. Doyle, B. Fane

Los Alamos National Laboratory

B. Ebbinghaus

Lawrence Livermore National Laboratory

August 2012

Nuclear Science and Technology Department

Brookhaven National Laboratory

\section{U.S. Department of Energy \\ DOE National Nuclear Security Administration}

Notice: This manuscript has been authored by employees of Brookhaven Science Associates, LLC under Contract No. DE-AC0298CH10886 with the U.S. Department of Energy. The publisher by accepting the manuscript for publication acknowledges that the United States Government retains a non-exclusive, paid-up, irrevocable, world-wide license to publish or reproduce the published form of this manuscript, or allow others to do so, for United States Government purposes. 


\section{DISCLAIMER}

This report was prepared as an account of work sponsored by an agency of the United States Government. Neither the United States Government nor any agency thereof, nor any of their employees, nor any of their contractors, subcontractors, or their employees, makes any warranty, express or implied, or assumes any legal liability or responsibility for the accuracy, completeness, or any third party's use or the results of such use of any information, apparatus, product, or process disclosed, or represents that its use would not infringe privately owned rights. Reference herein to any specific commercial product, process, or service by trade name, trademark, manufacturer, or otherwise, does not necessarily constitute or imply its endorsement, recommendation, or favoring by the United States Government or any agency thereof or its contractors or subcontractors. The views and opinions of authors expressed herein do not necessarily state or reflect those of the United States Government or any agency thereof.. 


\title{
BROOKHSWEN \\ NATIONAL LABORATORY
}

BNL-98372-2012

\section{THE INDIAN ADVANCED HEAVY WATER REACTOR (AHWR)} AND NON-PROLIFERATION ATTRIBUTES

\section{Todosow, A. Aronson, L. Cheng}

Brookhaven National Laboratory

\author{
R. Wigeland \\ Idaho National Laboratory
}

C. Bathke, C. Murphy, B. Boyer, J. Doyle, B. Fane

Los Alamos National Laboratory

B. Ebbinghaus

Lawrence Livermore National Laboratory 



\section{TABLE OF CONTENTS}

Page

LIST OF FIGURES ………………………………………………………………………. iv

LIST OF TABLES …………………………………………………………………….. iv

EXECUTIVE SUMMARY ………………………………………………………………... v

$1.0 \quad$ INTRODUCTION ......................................................................................... 1

$2.0 \quad$ THE AHWR REACTOR .................................................................................................. 3

$2.1 \quad$ The AHWR Fuel Cycle ………………………………………………………………. 8

$2.2 \quad$ Characteristics of Special Nuclear Materials (SNM) ................................................ 8

$2.3 \quad$ Fuel Handling and Storage ...................................................................................... 12

3.0 INITIAL OBSERVATIONS ON INTRINSIC DESIGN-RELATED NON-PROLIFERATION ATTRIBUTES...................................................................... 14

3.1 Possible Proliferation-Related Strengths ……………………………………………….... 15

$3.2 \quad$ Possible Proliferation-Related Weaknesses .................................................................. 15

4.0 REFERENCES ……………………………………………………………..... 17

APPENDIX A: CALCUATIONS OF FOM AND FOM $_{2}$ FOR MATERIAL ATTRACTIVENESS..................................................................... 18 


\section{LIST OF FIGURES}

Page

Figure 1: The Three-Stage Indian Nuclear Programme and the Use of the AHWR .............. 2

Figure 2: The AHWR Reactor System ...................................................................... 3

Figure 3: The AHWR Reactor Core …....................................................................... 4

Figure 4: The CANDU Calandria and Pressure Tube Concept Adopted for the AHWR Design 4

Figure 5: AHWR and AHWR-LEU Fuel Design, Fuel Cluster Parameters, and Fuel Cluster with Detail of the Lower End of the Cluster............................................. 6

Figure 6: AHWR “Fueling Machine” for Refueling the Reactor ....................................... 13

Figure 7: AHWR Fuel Handling System with the Inclined Fuel Transfer Machine ............... 13

\section{LIST OF TABLES}

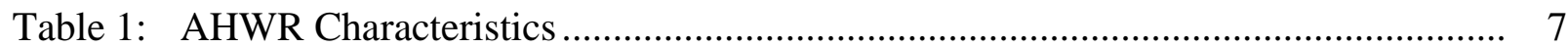

Table 2: Content of SNM Initially and at Discharge ................................................. 9

Table 3: Preliminary Results for AHWR SNM Content Based on an Independent DRAGON Calculation for a Single Calandria Tube 


\section{EXECUTIVE SUMMARY}

This report describes the Indian Advanced Heavy Water Reactor (AHWR), focusing on the reactor design and operational features that are relevant to proliferation risk, for both the AHWR intended for domestic use and the AHWR-LEU for export. The AHWR is the key component of the final stage of the three-stage Indian Nuclear program, "Thorium Utilization for Sustainable Power Programme," that has been in development since the 1950's. The nuclear program in India has historically assumed a heavy reliance on the ultimate transition to a thorium-based fuel cycle due to the abundant domestic thorium resources and the scarcity of domestic uranium. Both the AHWR and AHWR-LEU use thorium-based oxide fuels, with the AHWR using both $\mathrm{UO}_{2} / \mathrm{ThO}_{2}$ and $\mathrm{PuO}_{2} / \mathrm{ThO}_{2}$ fuels simultaneously, while AHWR-LEU uses only $\mathrm{UO}_{2} / \mathrm{ThO}_{2}$ fuel. The AHWRs are essentially derivatives of the advanced CANDU reactor, with the fuel oriented vertically instead of horizontally and refueling still occurring on-line, but only from the top of the reactor.

The Nuclear Power Corporation of India Ltd. (NPCIL) is responsible for design, construction, commissioning and operation of thermal nuclear power plants. They have stated that construction on the AHWR would start in 2014, with expected operation in 2019. The domestic AHWR uses a closed fuel cycle with recycle of ${ }^{233} \mathrm{U}$, plutonium, and thorium, consistent with the objective of the third stage of the Indian Nuclear Programme discussed above. As a result, the AHWR would not use natural or enriched uranium. All fuel could initially be $\mathrm{PuO}_{2} / \mathrm{ThO}_{2}$ until sufficient ${ }^{233} \mathrm{U}$ is available from the fast reactors of the second stage to allow operation of the AHWR with the equilibrium $\mathrm{UO}_{2} / \mathrm{ThO}_{2}$ and $\mathrm{PuO}_{2} / \mathrm{ThO}_{2}$ fuel compositions. AHWR fresh and spent fuels contain plutonium and ${ }^{233} \mathrm{U}$, both of which may represent a proliferation concern. Preliminary estimates of Figure-of-Merit $1\left(\mathrm{FOM}_{1}\right)$ show values for plutonium of 2.60 (fresh fuel) and 1.84 (spent fuel), where $\mathrm{FOM}_{1}$ values greater than 1.0 indicate attractiveness and values less than 1.0 indicate unattractive material. For reference, reactor grade plutonium has a $\mathrm{FOM}_{1}$ value of about 2.0. Similarly, FOM 1 values are 2.69 and 2.55, respectively, for the uranium which is mainly ${ }^{233} \mathrm{U}$, even in the presence of ${ }^{232} \mathrm{U}$, indicating that ${ }^{233} \mathrm{U}$ in used $\mathrm{UO}_{2} / \mathrm{ThO}_{2}$ fuel has similar material attractiveness to $\mathrm{Pu}$ in used $\mathrm{PuO}_{2} / \mathrm{UO}_{2}$ or $\mathrm{PuO}_{2} / \mathrm{ThO}_{2}$ fuel.

The export version, AHWR-LEU, operates with a once-through fuel cycle. In this case, only $\mathrm{UO}_{2} / \mathrm{ThO}_{2}$ fuel with enriched uranium $\left(19.75 \%{ }^{235} \mathrm{U}\right)$ is used, and there is lower breeding of ${ }^{233} \mathrm{U}$ since, by design, the system is not self-sustaining. As a result, for uranium, $\mathrm{FOM}_{1}$ is 1.0 in the fresh fuel and in the range of 0.63 to 0.94 in the spent fuel. There is no plutonium in the fresh fuel, and $\mathrm{FOM}_{1}$ for the plutonium in the spent fuel ranges from 1.68 to 2.06. In this sense, the potentially weapons-usable materials in AHWR-LEU are similar to those available with a typical LWR.

From this initial review, positive nonproliferation attributes for the two reactors are difficult to identify clearly, at least in comparison to existing LWR technology. The AHWR produces very little plutonium since there is no ${ }^{238} \mathrm{U}$ in the fuel, and has a low percentage of ${ }^{239} \mathrm{Pu}$ remaining in the spent fuel from the initial plutonium loading. It effectively burns the plutonium in the $\mathrm{PuO}_{2} / \mathrm{ThO}_{2}$ fuels used to drive the thorium to produce ${ }^{233} \mathrm{U}$. At the same time, it is very important to recognize that this positive attribute with respect to plutonium comes along with the negative attributes of the highly attractive ${ }^{233} \mathrm{U}$ in the spent fuel, so that in effect, a trade has been 
made, and when all is considered, it appears that any benefit from the greatly reduced plutonium content is offset by the production of highly attractive uranium. However, the presence of ${ }^{232} \mathrm{U}$ may potentially complicate attempts at proliferation due to the emission of $2.6 \mathrm{MeV}$ gamma radiation making the uranium difficult to shield and easy to detect.

The AHWR-LEU, as the name suggests, uses low enriched uranium fuel and produces plutonium from ${ }^{238} \mathrm{U}$, just as in an LWR. The plutonium in the used fuel has 4 to $10 \%{ }^{238} \mathrm{Pu}$ and 41 to $54 \%$ ${ }^{239} \mathrm{Pu}$, similar in attractiveness to reactor grade plutonium from an LWR, but with a quantity that is about $10 \%$ lower than in a PWR.

It is also difficult to clearly identify specific negative nonproliferation aspects for these two reactors in comparison to existing LWR technology. Both the AHWR and AHWR-LEU use heavy water, a material of concern with regards to proliferation since use in reactors will allow production of weapons-grade plutonium from natural uranium. Given the high thermal crosssection of ${ }^{232} \mathrm{Th}$, use of thorium in heavy-water moderated reactors will also be effective at producing ${ }^{233} \mathrm{U}$. As with other reactors, it is possible to misuse the AHWR and AHWR-LEU for efficient ${ }^{233} \mathrm{U}$ or plutonium production.

The intent is to process spent AHWR fuel using a three-stream separation technique for the uranium, plutonium and thorium, which will create opportunities for diversion of nuclear material, as with any processing approach. Any country with the full system may also have gained technical knowledge and experience that would be useful for taking a plutonium or ${ }^{233} \mathrm{U}$ path to weapons production.

The fresh fuel of the AHWR-LEU contains $19.75 \%$ enriched ${ }^{235} \mathrm{U}$ (HEU is uranium enriched to greater than or equal to $20 \%{ }^{235} \mathrm{U}$ ), whereas the more commonly used LWR fuel is 3 to $5 \%$ enriched in ${ }^{235} \mathrm{U}$. Because the export reactor will not have reprocessing and fuel fabrication facilities, both fresh and spent fuel shipments across international borders will frequently occur, which could pose physical protection risks for the AHWR-LEU fresh fuel since it may be an attractive theft target. Depending on where the uranium enrichment facilities are, any shipments of $\mathrm{UF}_{6}$ to the fuel fabrication facility would also be attractive targets.

Additionally, the AHWR-LEU will produce plutonium, albeit in smaller quantities with lower ${ }^{239} \mathrm{Pu}$ content relative to a PWR. However, the isotopic composition of the plutonium is variable since burnup is easily adjustable in a reactor that is capable of on-line refueling, such as the AHWR-LEU. It is possible, although not ideal, to use the plutonium produced in the AHWRLEU in a weapon, once again representing a proliferation risk in a variety of settings. 


\subsection{INTRODUCTION}

India is developing the Advanced Heavy Water Reactor (AHWR) as a key element of its Nuclear Programme as shown in Figure 1, which assumes ultimate reliance on the ${ }^{233} \mathrm{U}$-thorium fuel cycle. The Nuclear Power Corporation of India Ltd. (NPCIL) is responsible for design, construction, commissioning and operation of thermal nuclear power plants. They have stated that construction on the AHWR would start in 2014, with expected operation in 2019. As with the Canada Deuterium Uranium (CANDU) reactor, the AHWR uses oxide fuel but uses a combination of $\mathrm{UO}_{2} / \mathrm{ThO}_{2}$ and $\mathrm{PuO}_{2} / \mathrm{ThO}_{2}$ fuel. The AHWR operates with a closed fuel cycle, intended for deployment in India. A similar concept, the Advanced Heavy Water Reactor - Low Enriched Uranium (AHWR-LEU), operates with $\mathrm{UO}_{2} / \mathrm{ThO}_{2}$ using low-enriched uranium (LEU) enriched to $19.75 \%$ in ${ }^{235} \mathrm{U}$, but the reactor operates on a once-through fuel cycle and is for export.

This report briefly describes the key features of the AHWR and AHWR-LEU with a focus on those aspects that relate to intrinsic proliferation risk, i.e., those aspects of the AHWR that are inherently part of the design and operation, such as quantities and isotopic distribution of special nuclear material (SNM), and fuel handling and storage, and does not address issues related to safeguards or safeguardability of the AHWR and its associated facilities. Section 3 and Appendix A provide an initial evaluation of such intrinsic proliferation-related attributes. Design-related information is from numerous sources, with References [1] and [2] being representative of the most recent comprehensive documents. It is important to note that the AHWR design appears to still be evolving, with the result that there are inconsistencies in the information among the various sources. As a consequence, the details and quantitative data discussed in this report are only "representative" at this stage and are subject to change. 


\section{Three Stage Indian Nuclear Programme}

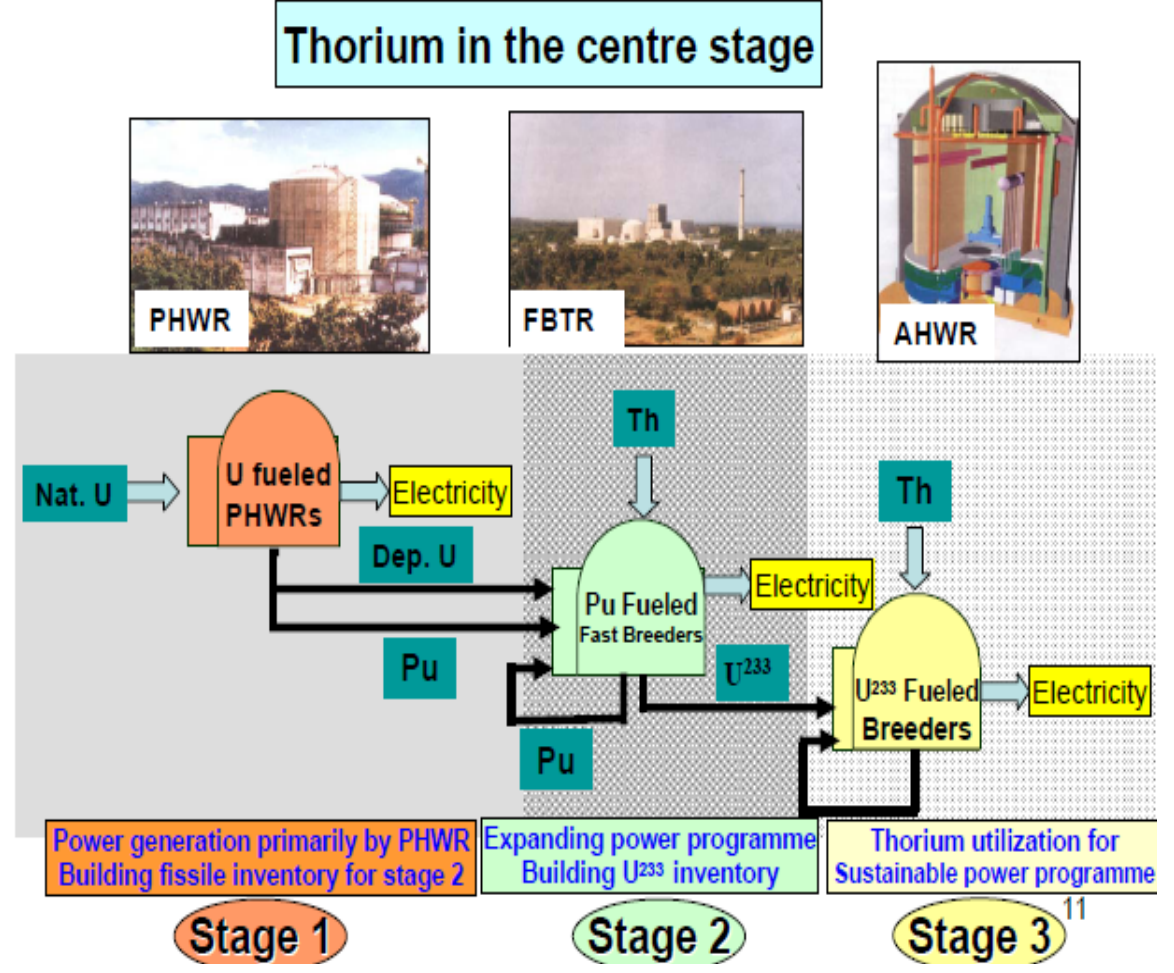

Figure 1. The Three-Stage Indian Nuclear Programme and the Use of the AHWR 


\subsection{THE AHWR REACTOR}

The AHWR reactor is similar to advanced CANDU reactor designs, with pressure tubes containing the reactor fuel and light water reactor coolant located inside of calandria tubes, surrounded by a low-pressure reactor vessel filled with heavy water that serves as both moderator and reflector, as shown in Figures 2, 3, and 4. Air fills the annulus between each pressure tube and calandria tube to provide thermal insulation between the hot pressure tube and the cooler external heavy water moderator. Use of light water for the coolant follows the approach used for advanced CANDU designs, although most existing CANDU reactors utilize heavy water for the reactor coolant as well as for the moderator. However, the AHWR is a boiling water reactor and uses vertical pressure tubes instead of horizontal pressure tubes. As a result, the AHWR refuels only from the top of the reactor. In addition, each pressure tube in the AHWR contains only one long fuel "cluster," as compared to the multiple shorter fuel bundles in a typical CANDU reactor pressure tube. Coolant flow through the reactor core is provided via natural circulation driven by coolant boiling (there are no primary coolant pumps), and there is significant boiling in the core with an average steam quality of $18.2 \%$. The reactor core also contains control rods for shut down, reactivity control, and spatial power distribution.

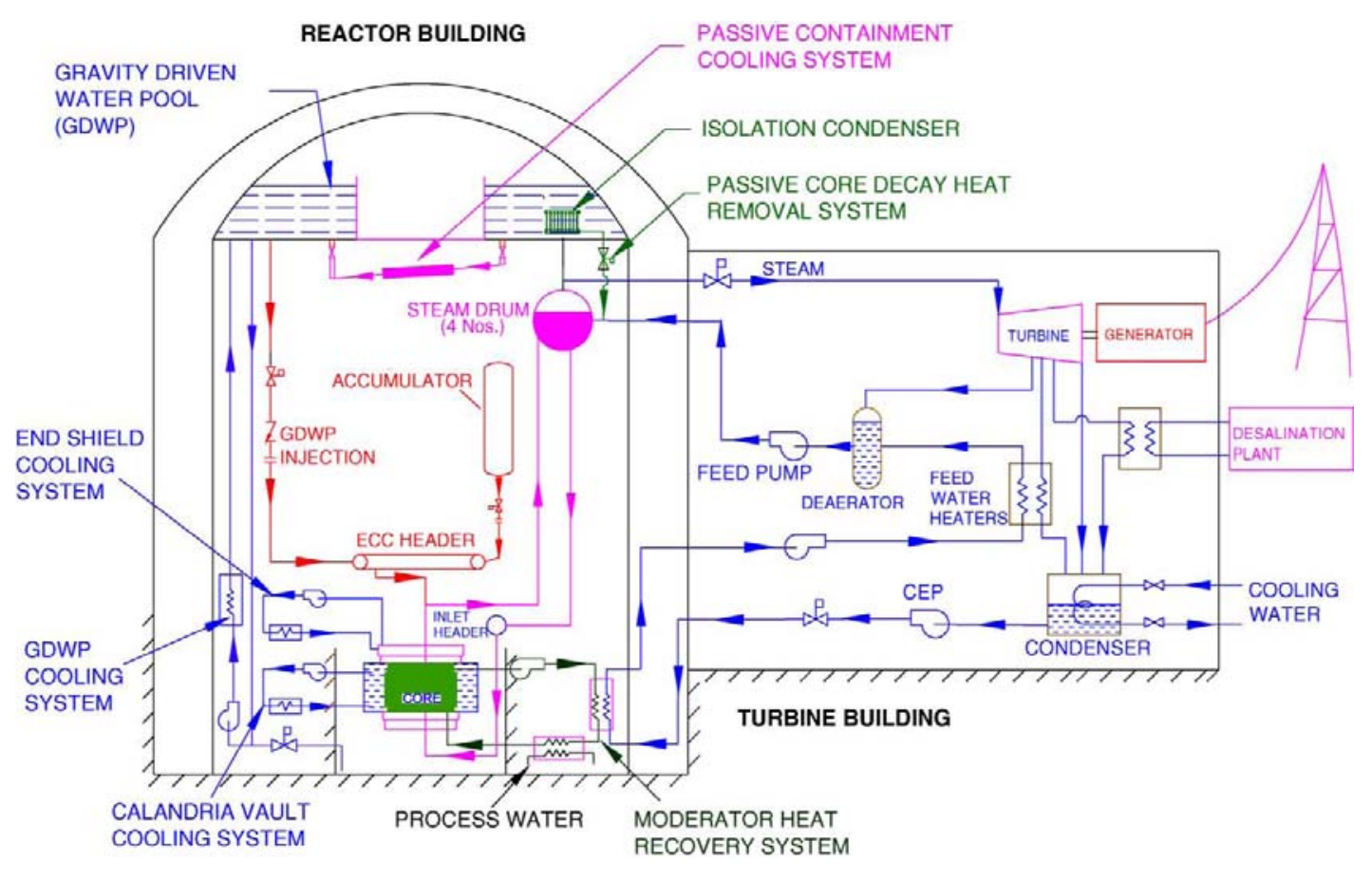

Figure 2. The AHWR Reactor System 


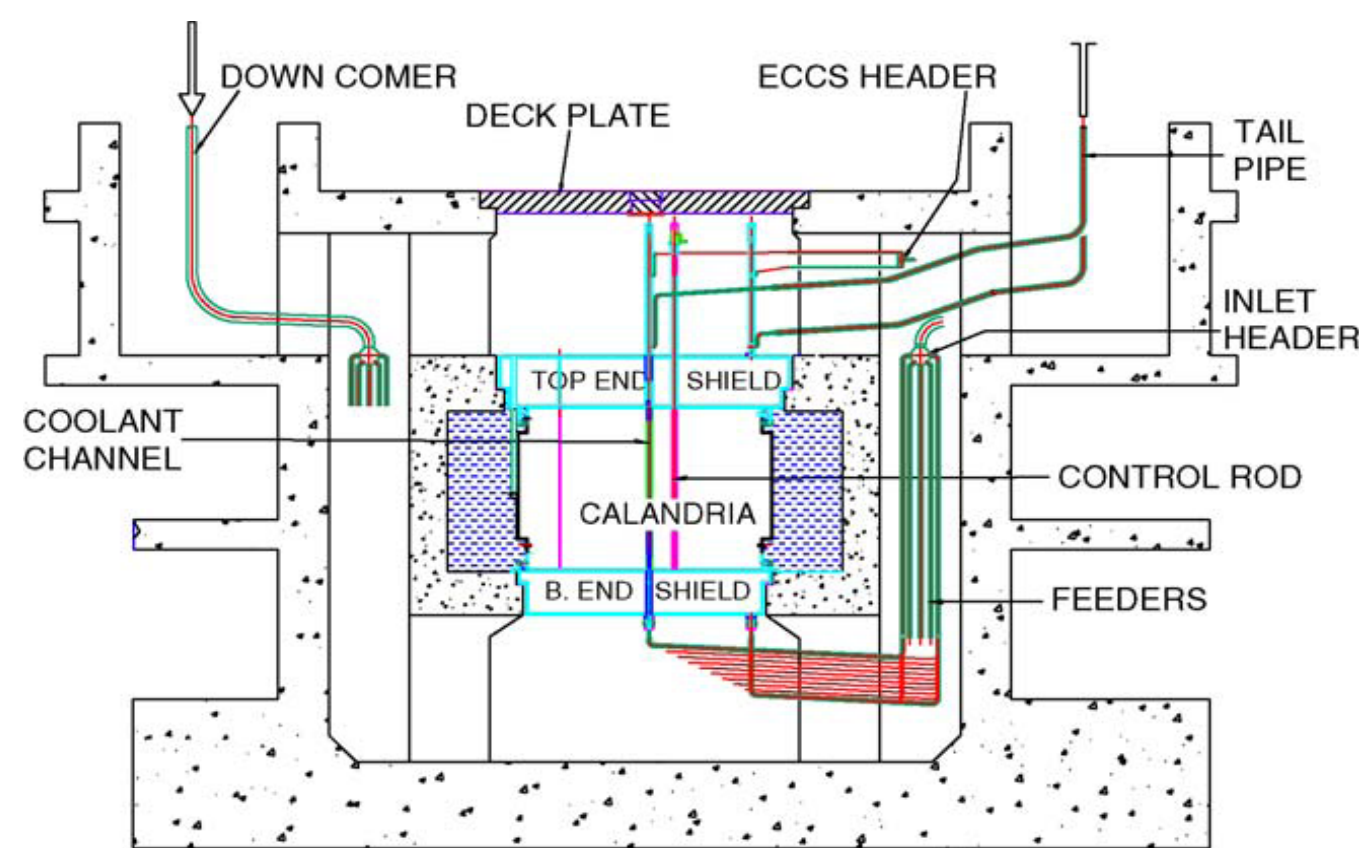

Figure 3. The AHWR Reactor Core

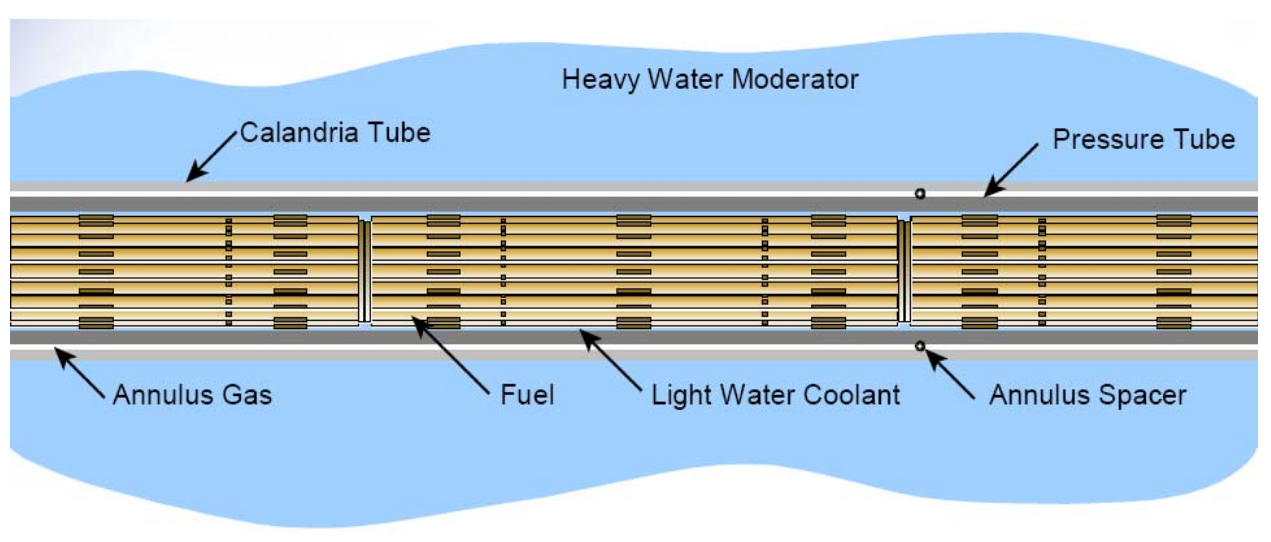

Figure 4. The CANDU Calandria and Pressure Tube Concept Adopted for the AHWR Design 
Figure 5 shows the AHWR fuel element cluster which consists of 54 fuel pins arranged in three concentric rings around a central rod. Each fuel pin contains fuel pellets in Zircaloy- 2 clad tubes (3500 mm in length). The fuel element cluster along with shielding is assembled into a "fuel assembly" so that each fuel assembly inserted in the reactor consists of three sections: the fuel element cluster and two shield sub-assembly sections, which are attached above the fuel cluster with collet joints, making the overall length of the fuel assembly $10.5 \mathrm{~m}$. The use of a single fuel assembly in each pressure tube is necessary due to the vertical orientation of the pressure tubes in the reactor. (This is in stark contrast to the advanced CANDU design, where multiple $(\sim 12)$ short independent fuel bundles are contained within each horizontal pressure tube, facilitating refueling from either end of the CANDU reactor.) The fuel in the two inner rings of an AHWR fuel cluster contains $\mathrm{UO}_{2}$ in $\mathrm{ThO}_{2}$ where the $\mathrm{UO}_{2}$ is mainly ${ }^{233} \mathrm{U}$. The uranium percentage in the $\mathrm{UO}_{2} / \mathrm{ThO}_{2}$ fuel is $3 \% \mathrm{UO}_{2}$ in $\mathrm{ThO}_{2}$ in the inner ring and $3.75 \% \mathrm{UO}_{2}$ in $\mathrm{ThO}_{2}$ in the middle ring. The outer ring contains $\mathrm{PuO}_{2}$ in $\mathrm{ThO}_{2}$ in two axial zones, $4.0 \% \mathrm{PuO}_{2}$ in the bottom (B) half of the cluster and $2.5 \% \mathrm{PuO}_{2}$ in the top (T) half of the cluster. No natural or enriched uranium is used. The radial and axial variation of fissile loading controls the power/critical heat flux ratio, a standard design parameter that is even more important in this design due to the use of natural circulation cooling of the reactor core at full power. Like the CANDU reactor, the AHWR refuels while the reactor is at power.

The AHWR-LEU fuel element cluster has the same construction as the AHWR, but the fuel composition is entirely different. All fuel is $\mathrm{UO}_{2}$ in $\mathrm{ThO}_{2}$, and all uranium is enriched to $19.75 \%$ ${ }^{235} \mathrm{U}$ (still LEU). The uranium percentage in the $\mathrm{UO}_{2} / \mathrm{ThO}_{2}$ fuel is different in each of the three rings, with up to $18 \% \mathrm{UO}_{2}$ in $\mathrm{ThO}_{2}$ in the inner ring, up to $22 \% \mathrm{UO}_{2}$ in $\mathrm{ThO}_{2}$ in the middle ring, and up to $22.5 \%$ in the outer ring. Figure 5 and Table 1 list key design parameters for the AHWR and AHWR-LEU. 


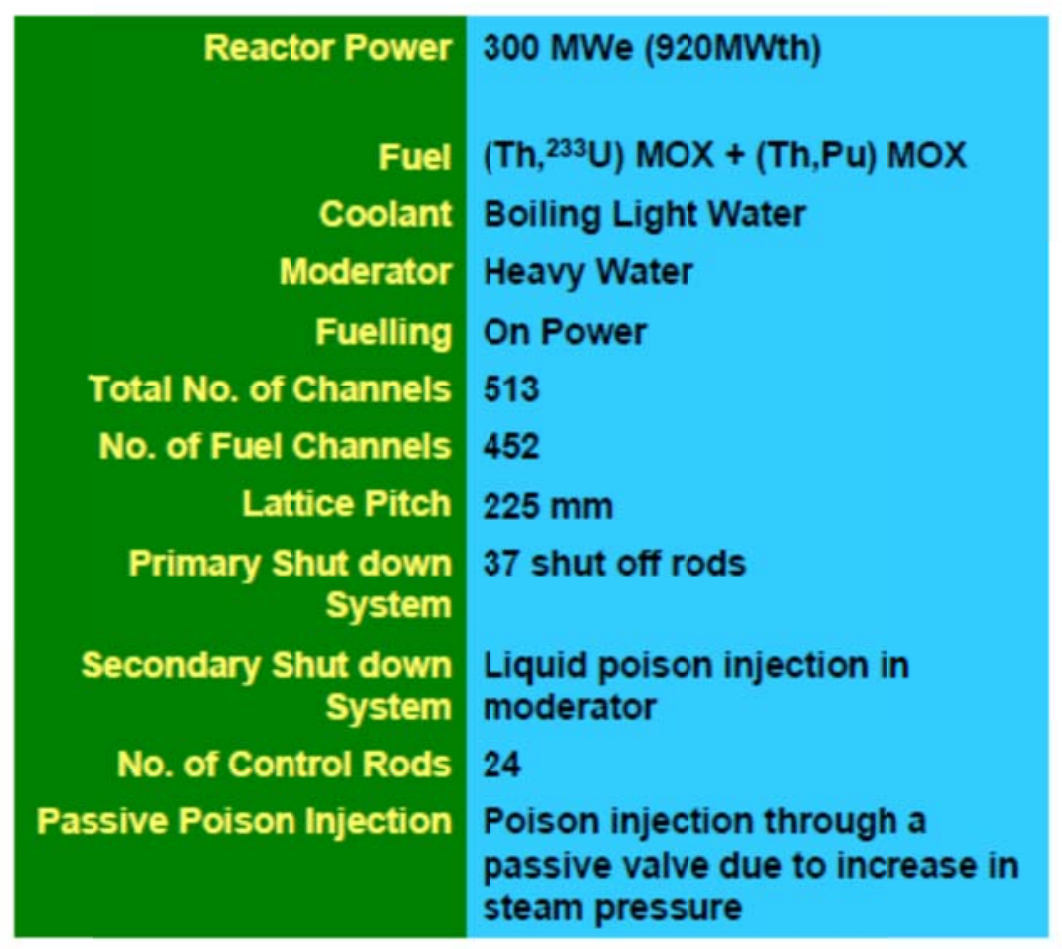

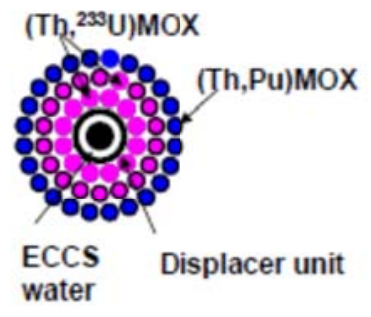

Inner Ring (12 pins) 3\% ${ }^{233} \mathrm{UO}_{2}$ in $\mathrm{ThO}_{2}$

Middle Ring (18 pins) $3.75 \%$ ${ }^{233} \mathrm{UO}_{2}$ in $\mathrm{ThO}_{2}$

Outer ring ( 24 pins)

4.0\% $\mathrm{PuO}_{2}$ in $\mathrm{ThO}_{2}$ (Bottom half)

$2.5 \% \mathrm{PuO}_{2}$ in $\mathrm{ThO}_{2}$ (Top half)

The Displacer unit having central displacer rod (lower half of Zircaloy and upper half of SS) placed within zircaloy tube which is filled with EGQS water

In AHWR 300-LEU, LEU-Th MOX fuel is used in place of Th- ${ }^{233} \mathrm{U}$ and Th-Pu Mox used in AHWR
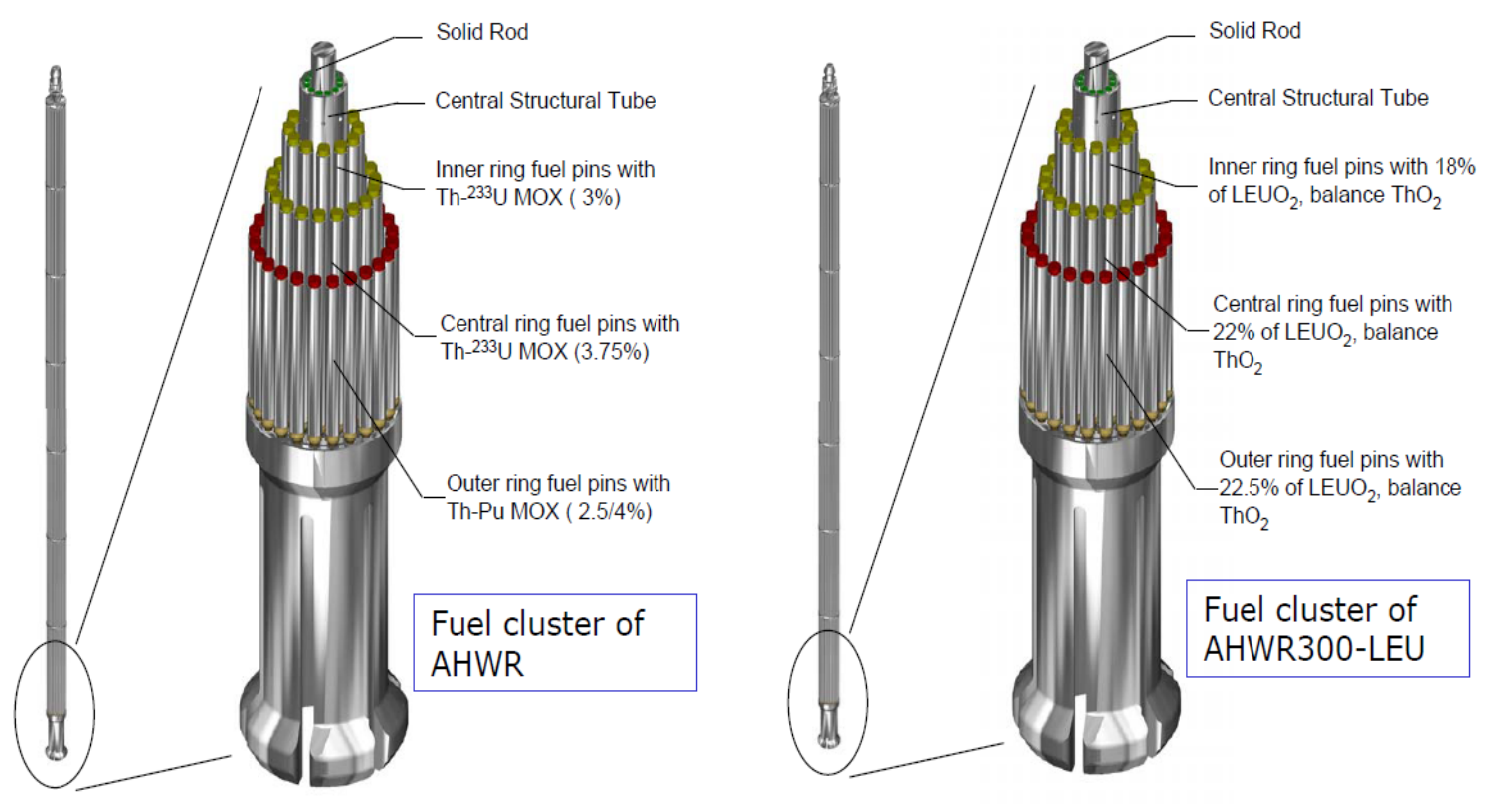

Figure 5. AHWR and AHWR-LEU Fuel Design, Fuel Cluster Parameters, and Fuel Cluster with Detail of the Lower End of the Cluster 
Table 1. AHWR Characteristics

\begin{tabular}{|c|c|c|}
\hline Parameter & Reference AHWR & $\begin{array}{l}\text { AHWR-LEU } \\
\text { Low-High }\end{array}$ \\
\hline Thermal Power (MWth) & 920 & 920 \\
\hline Electrical Power (MWe) & 300 & 300 \\
\hline $\begin{array}{l}\text { Fuel } \\
\text { Inner ring (12 pins) } \\
\text { Middle ring (18 pins) } \\
\text { Outer ring (24 pins) }\end{array}$ & $\begin{array}{c}\text { All } \mathrm{UO}_{2} \text { is mainly }{ }^{233} \mathrm{U} \\
\mathrm{UO}_{2}(3 \mathrm{wt} \%) \text { in } \mathrm{ThO}_{2} \\
\mathrm{UO}_{2}(3.75 \mathrm{wt} \%) \text { in } \mathrm{ThO}_{2} \\
\mathrm{PuO}_{2}(4 \mathrm{wt} \%) \text { in } \mathrm{ThO}_{2}(\mathrm{~B}) \\
\mathrm{PuO}_{2}(2.5 \mathrm{wt} \%) \text { in } \mathrm{ThO}_{2}(\mathrm{~T}) \\
\end{array}$ & $\begin{array}{l}\text { All } \mathrm{UO}_{2} \text { is } 19.75 \text { wt\% }{ }^{235} \mathrm{U} \\
\mathrm{UO}_{2}\left(13-18 \text { wt\%) in } \mathrm{ThO}_{2}\right. \\
\mathrm{UO}_{2}\left(17.5-22 \text { wt\%) in } \mathrm{ThO}_{2}\right. \\
\mathrm{UO}_{2}\left(15-22.5 \text { wt\%) in } \mathrm{ThO}_{2}\right.\end{array}$ \\
\hline Fueling requirement (channels/yr) & & $90-44$ \\
\hline Number of Core Channels & 513 & 505 \\
\hline Number of Fuel Channels & 452 & 452 \\
\hline Number of Control Rods & 24 & 12 \\
\hline Number of Shut-off Rods & 37 & 41 \\
\hline Power/channel (MWth) & 2.04 & 2.04 \\
\hline Average discharge burnup, GWd/te & 38 & $31-64$ \\
\hline $\begin{array}{l}\text { Burnup by Zone (GWd/te) } \\
\text { LEU-low } \\
\text { LEU-high } \\
\end{array}$ & & $\begin{array}{c}41.25 / 3.0 / 26.25 \\
74.0 / 64.0 / 61.0 \\
\end{array}$ \\
\hline Annual LEU requirement, $\mathrm{kg}$ & & 1599-1095 \\
\hline $\begin{array}{l}\text { Energy extracted per ton of equivalent } \\
\text { mined uranium, MWd }\end{array}$ & & $5255-7828$ \\
\hline Power from ${ }^{233} \mathrm{U}$ bred from thorium, $\%$ & 65 & $30-39$ \\
\hline $\begin{array}{l}\text { Peaking Factors (maximum): } \\
\text { Local/ Radial/ Axial/ Total }\end{array}$ & & $\begin{array}{c}1.22-1.35 / 1.18-1.2 / \\
1.5-1.36 / 2.2 \\
\end{array}$ \\
\hline
\end{tabular}




\subsection{The AHWR Fuel Cycle}

The AHWR operates in a closed fuel cycle with recycle of both ${ }^{233} \mathrm{U}$ and thorium back into the reactor. On-line refueling is the reference operating mode, with batch refueling during shutdown as an option. The currently envisaged [1] fuel cycle assumes that the fuel will reside in the reactor for a total of 4 years, followed by 2 years for cooling, 1 year for reprocessing and 1 year for re-fabrication into new fuel. The core design facilitates breeding ${ }^{233} \mathrm{U}$ from ${ }^{232} \mathrm{Th}$ and is selfsustaining in combination with the fast reactor of the second stage, i.e., overall creation of new fissile $\left({ }^{233} \mathrm{U}\right)$ combined with the makeup plutonium from spent PHWR fuel [1] equals the fissile consumed during the AHWR cycle. However, the initial core and reload fuel consists only of $\mathrm{PuO}_{2} / \mathrm{ThO}_{2}$ until sufficient ${ }^{233} \mathrm{U}$ is available from the fast reactor of the second stage to provide the fuel pin loadings for the inner and middle rings as listed in Table 1. Processing to extract and fabricate the ${ }^{233} \mathrm{U}$-containing spent AHWR fuel is highly automated and remote and performed in a co-located facility, which will include reprocessing, waste management and fuel fabrication to minimize the time between separation and fuel fabrication since the ${ }^{232} \mathrm{U}$ content increases after separation, complicating operations and handling due to the high-energy gamma source.

Prior to reprocessing, fuel cluster disassembly segregates the two different fuel pin types: structural materials and any burnable absorbers. Different reprocessing methods for the two fuel pin types separate thorium, uranium and plutonium products. Fabrication of new $\mathrm{UO}_{2} / \mathrm{ThO}_{2}$ fuel pins immediately uses approximately half of the reprocessed thorium. The remaining thorium is stored until its radioactivity has decreased sufficiently for handling with minimum shielding and stored until use for fabrication of $\mathrm{PuO}_{2} / \mathrm{ThO}_{2}$ fuel pins. Overall, $60 \%$ of the power generated by the reactor comes from the ${ }^{233} \mathrm{U}$ created from thorium.

\subsection{Characteristics of Special Nuclear Materials (SNM)}

The AHWR spent fuel contains both plutonium and ${ }^{233} \mathrm{U}$, while the AHWR-LEU spent fuel contains ${ }^{233} \mathrm{U}$, all of which may be usable in nuclear weapons and may represent a proliferation concern. Table 2 contains initial and discharge uranium and plutonium masses $(\mathrm{g} / \mathrm{kg})$ and isotopic distributions from Reference [2]. Also included in Table 2 are preliminary calculations of $\mathrm{FOM}_{1}$ and $\mathrm{FOM}_{2}$, with the derivation in Appendix A. The Indian project materials state that "The $U$ contains sufficient quantity of ${ }^{232} U$ and is proliferation resistant." Low FOMs indicate low material attractiveness and low weapons utility (i.e., difficult to be utilized in a weapon), usually indicated by FOM values less than one. The FOM 1 values for uranium in the AHWR are 2.69 and 2.55 at charge and discharge, respectively, which means that the amount of ${ }^{232} U$ in the uranium is not sufficient to lower the material attractiveness of the ${ }^{233} \mathrm{U}$ below that of reactor grade plutonium. Thus, these analyses do not support the statement in the Indian project materials, and based on the $\mathrm{FOM}_{1}$ values, the ${ }^{233} \mathrm{U}$ is possibly less "proliferation resistant" than reactor grade plutonium. However, for the AHWR-LEU, FOM 1 for uranium is 1.00 at charge and in the range of 0.63-0.94 at discharge due to the use of low enriched uranium which has a large percentage of ${ }^{238} \mathrm{U}$. 
Table 2. Content of SNM Initially and at Discharge

\begin{tabular}{|c|c|c|}
\hline Parameter & AHWR & $\begin{array}{l}\text { AHWR-LEU } \\
\text { Low-High }\end{array}$ \\
\hline $\begin{array}{c}P u(g / k g) \\
\text { Initial } \\
\text { Output }\end{array}$ & $\begin{array}{l}14.4 \\
2.66\end{array}$ & \\
\hline $\begin{array}{c}\mathrm{U}(\mathrm{g} / \mathrm{kg}) \\
\text { Initial } \\
\text { Output }\end{array}$ & $\begin{array}{l}19.2 \\
20.1\end{array}$ & \\
\hline $\begin{array}{c}\text { MA (g/kg) } \\
\text { Initial } \\
\text { Output }\end{array}$ & - & \\
\hline $\begin{array}{l}\text { Pu-vector (initial) } \\
{ }^{238} \mathrm{Pu} \\
{ }^{239} \mathrm{Pu} \\
{ }^{240} \mathrm{Pu} \\
{ }^{241} \mathrm{Pu} \\
{ }^{242} \mathrm{Pu} \\
\mathrm{FOM}_{1} \\
\mathrm{FOM}_{2}\end{array}$ & $\begin{array}{l}0.0 \\
68.79 \\
24.6 \\
5.26 \\
1.35 \\
2.60 \\
1.26\end{array}$ & \\
\hline $\begin{array}{l}\text { Pu-vector } \\
\text { (discharge -38GWd/te) } \\
{ }_{238} \mathrm{Pu} \\
{ }^{239} \mathrm{Pu} \\
{ }^{240} \mathrm{Pu} \\
{ }^{241} \mathrm{Pu} \\
{ }^{242} \mathrm{Pu} \\
\mathrm{FOM}_{1} \\
\mathrm{FOM}_{2}\end{array}$ & $\begin{array}{c}2.29 \\
1.61 \\
31.12 \\
21.24 \\
43.74 \\
1.84 \\
0.29 \\
\end{array}$ & $\begin{array}{c}3.63-9.62 \\
53.84-41.28 \\
21.69-21.17 \\
14.34-13.85 \\
6.51-14.09 \\
2.06-1.68 \\
1.02-0.75\end{array}$ \\
\hline $\begin{array}{l}\text { U-vector (initial) } \\
{ }^{232} \mathrm{U} \\
{ }^{233} \mathrm{U} \\
{ }^{234} \mathrm{U} \\
{ }^{235} \mathrm{U} \\
{ }^{236} \mathrm{U} \\
{ }^{238} \mathrm{U} \\
\mathrm{FOM}_{1} \\
\mathrm{FOM}_{2} \\
\end{array}$ & $\begin{array}{c}0.0 \\
100.0 \\
0.0 \\
0.0 \\
0.0 \\
0.0 \\
2.69 \\
2.69\end{array}$ & $\begin{array}{c}0.0 \\
0.0 \\
0.0 \\
19.75 \\
0.0 \\
80.25 \\
1.00 \\
1.00 \\
\end{array}$ \\
\hline $\begin{array}{l}\text { U-vector } \\
\text { (discharge -38GWd/te) } \\
{ }^{232} \mathrm{U} \\
{ }^{233} \mathrm{U} \\
{ }^{234} \mathrm{U} \\
{ }^{235} \mathrm{U} \\
{ }^{236} \mathrm{U} \\
{ }^{238} \mathrm{U} \\
\mathrm{FOM}_{1} \\
\mathrm{FOM}_{2}\end{array}$ & $\begin{array}{c}0.14 \\
83.15 \\
14.10 \\
2.32 \\
0.28 \\
0.0 \\
2.55 \\
2.55\end{array}$ & $\begin{array}{c}0.01-0.02 \\
7.53-6.53 \\
0.78-1.27 \\
4.93-1.52 \\
2.67-3.25 \\
84.08-87.41 \\
0.94-0.63 \\
0.94-0.62\end{array}$ \\
\hline
\end{tabular}


There are ranges of published data for spent fuel compositions in both of these reactors, as shown in Table 2 [2]. The results of independent calculations to verify the published results showed that the range of results is sufficiently representative. The calculations estimated the neutronics performance of an AHWR calandria tube, containing the fuel cluster and light water coolant, using DRAGON with ENDF/B-VII cross sections based on available published data and estimates for missing data on geometry and initial compositions required to complete the modeling. Table 3 summarizes the results for key parameters relevant to proliferation issues (uranium and plutonium loadings, material attractiveness, and isotopic composition) and the results are consistent with published data from various Indian presentations and publications, given the preliminary nature of the calculations and the lack of complete and consistent design data for AHWR. This result supports use of the data for the $\mathrm{FOM}_{1}$ estimates of material attractiveness listed in Table 2 for AHWR and AHWR-LEU.

Efforts are currently underway to obtain a preliminary estimate of the dose from a fuel cluster at discharge. ORIGEN calculations provided spent fuel compositions, and the resulting 18-group gamma source will provide the input for dose calculations using MICROSHIELD assuming a homogeneous distributed volume source. 
Table 3. Preliminary Results for AHWR SNM Content Based on an Independent DRAGON Calculation for a Single Calandria Tube

\begin{tabular}{|c|c|c|c|c|c|}
\hline Burnup (MWd/T) & $3.79 \mathrm{E}+04$ & & & & \\
\hline & $\frac{\text { Inner }}{\text { Ring }}$ & $\frac{\text { Middle }}{\text { Ring }}$ & $\frac{\text { Outer }}{\text { Ring }}$ & Calculated & $\begin{array}{l}\frac{\text { From AHWR }}{\text { Documents }} \\
\text { @38 GWd/T }\end{array}$ \\
\hline uranium total $(\mathrm{kg})$ & 0.593 & 0.941 & 0.783 & 2.317 & \\
\hline uranium (gm/kg) & 21.967 & 23.445 & 14.706 & 19.249 & 20.100 \\
\hline $\begin{array}{l}\text { uranium vector } \\
(\%)\end{array}$ & & & & & \\
\hline $\begin{array}{l}{ }^{232} U \\
{ }^{233} U \\
{ }^{234} U \\
{ }^{235} U \\
{ }^{236} U \\
{ }^{237} U \\
{ }^{238} U\end{array}$ & $\begin{array}{r}0.113 \\
84.133 \\
13.671 \\
1.895 \\
0.189 \\
0.000 \\
0.000\end{array}$ & $\begin{array}{r}0.114 \\
81.488 \\
15.868 \\
2.265 \\
0.265 \\
0.000 \\
0.000\end{array}$ & $\begin{array}{r}0.180 \\
85.150 \\
12.684 \\
1.727 \\
0.258 \\
0.000 \\
0.000\end{array}$ & $\begin{array}{r}0.136 \\
83.402 \\
14.230 \\
1.989 \\
0.243 \\
0.000 \\
0.000\end{array}$ & $\begin{array}{c}0.14 \\
83.15 \\
14.1 \\
2.32 \\
0.28\end{array}$ \\
\hline $\mathrm{FOM}_{1}$ & 2.57 & 2.56 & 2.54 & 2.56 & 2.55 \\
\hline $\mathrm{FOM}_{2}$ & 2.57 & 2.56 & 2.54 & 2.56 & 2.55 \\
\hline $\begin{array}{l}\text { plutonium total } \\
(\mathrm{kg})\end{array}$ & 0.000 & 0.000 & 0.361 & 0.361 & \\
\hline $\begin{array}{l}\text { plutonium } \\
(\mathrm{gm} / \mathrm{kg})\end{array}$ & 0.000 & 0.000 & 6.784 & 3.001 & 2.66 \\
\hline $\begin{array}{l}\text { plutonium vector } \\
(\%)\end{array}$ & & & & & \\
\hline $\begin{array}{l}{ }^{238} \mathrm{Pu} \\
{ }^{239} \mathrm{Pu} \\
{ }^{240} \mathrm{Pu} \\
{ }^{241} \mathrm{Pu} \\
{ }^{242} \mathrm{Pu}\end{array}$ & $\begin{array}{r}88.276 \\
9.531 \\
1.610 \\
0.512 \\
0.071\end{array}$ & $\begin{array}{r}0.000 \\
96.934 \\
2.289 \\
0.668 \\
0.107\end{array}$ & $\begin{array}{r}2.063 \\
1.186 \\
35.726 \\
17.059 \\
43.965\end{array}$ & $\begin{array}{r}2.065 \\
1.189 \\
35.727 \\
17.059 \\
43.965\end{array}$ & \begin{tabular}{|c|}
2.29 \\
1.61 \\
31.12 \\
21.24 \\
43.74
\end{tabular} \\
\hline $\mathrm{FOM}_{1}$ & 0.96 & 2.76 & 1.83 & 1.83 & 1.84 \\
\hline $\mathrm{FOM}_{2}$ & 0.35 & 2.26 & 0.23 & 0.23 & 0.29 \\
\hline
\end{tabular}




\subsection{Fuel Handling and Storage}

As noted above, refueling of the AHWR can be either on-line during power operation or via batch mode when the reactor is shutdown, but the reactor only refuels from the top. The key elements of the fuel handling system and their functions are:

- $\quad$ The "Fueling Machine” (see Figure 6) for inserting and removing fuel assemblies moves on rails on the top of the reactor. The fueling machine operates remotely and consists of a ram assembly, magazine assembly, snout assembly, separator assembly and its trolley and carriage assembly. During refueling operations, the machine moves to the desired location over the reactor, makes a leak-tight connection with the selected coolant channel and performs all the required operations of removing seal plugs, extracting and disassembling the shield elements from the fuel cluster, and then performing the reverse operation with a fresh fuel cluster. A magazine assembly consists of eight tubes which temporarily store the various components throughout the process. The machine picks up fresh fuel from, and deposits spent fuel in, the "Temporary Fuel Storage Bay."

- $\quad$ The "Inclined Fuel Transfer Machine" (see Figure 7) moves fuel between the reactor building and the fuel building

- $\quad$ The "Temporary Fuel Storage Bay" located inside the reactor building is the location where spent fuel discharged from the reactor is stored prior to transfer out of the reactor building, and fresh fuel is stored prior to insertion in the reactor.

- The "Fuel Storage Bay" is located in the fuel building adjoining the reactor and stores fresh and spent fuel under water. The capacity assumes a refueling frequency of onefourth of the core per year, a 2-year cooling period for discharged fuel, and a 6-month inventory of fresh fuel. 


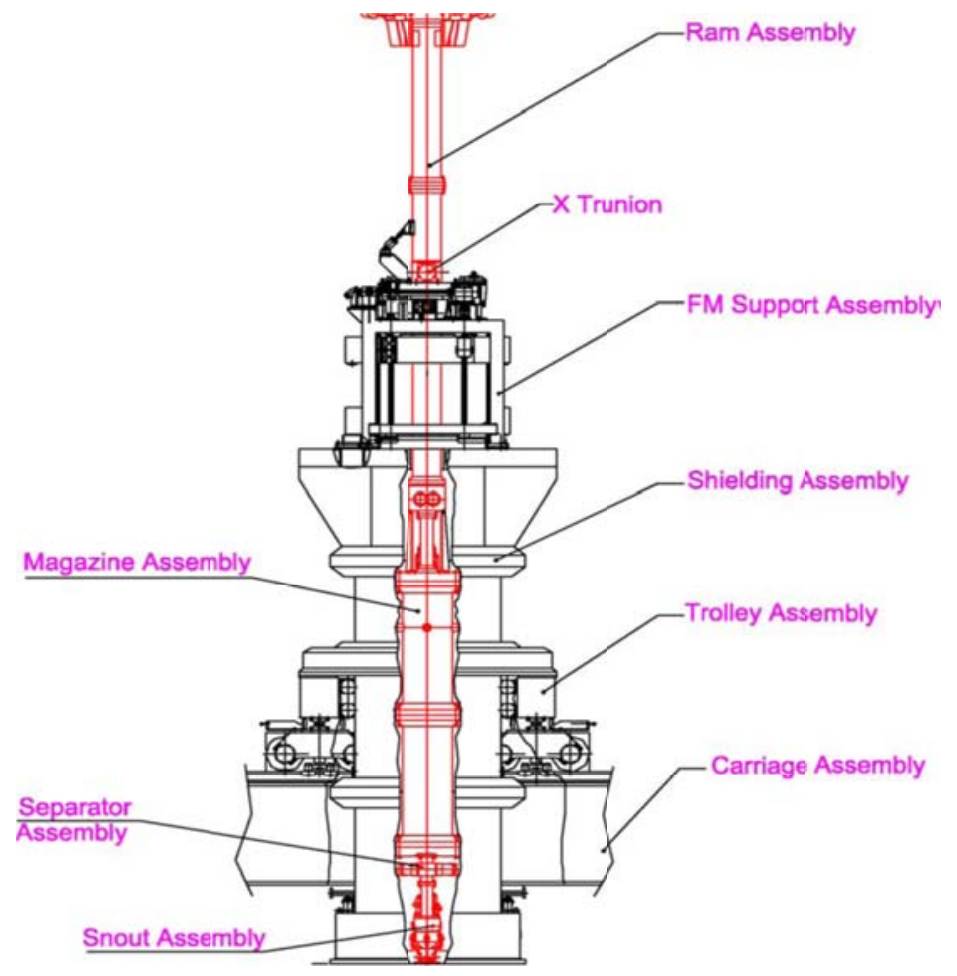

Figure 6. AHWR “Fueling Machine” for Refueling the Reactor

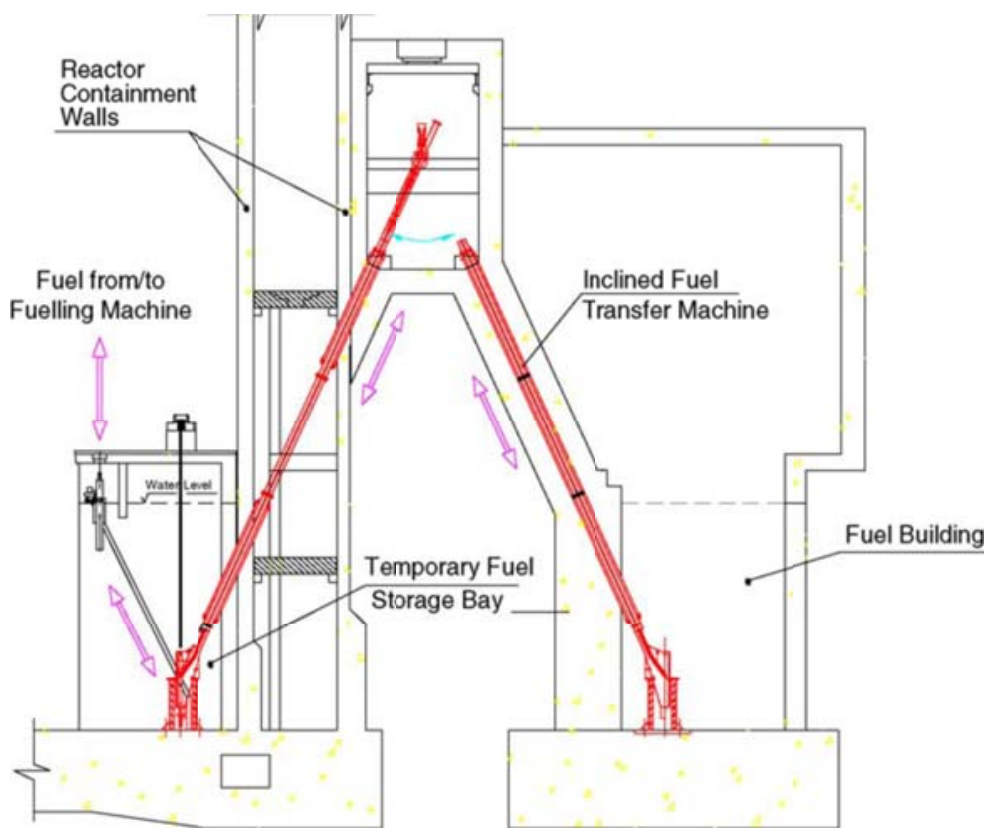

Figure 7. AHWR Fuel Handling System with the Inclined Fuel Transfer Machine 


\subsection{INITIAL OBSERVATIONS ON INTRINSIC DESIGN-RELATED NON-PROLIFERATION ATTRIBUTES}

Some preliminary observations on the potential non-proliferation attributes of the AHWR and AHWR-LEU are as follows:

- $\quad$ Under nominal operating conditions, the spent fuel compositions are as given in Tables 2 and 3, with $\mathrm{FOM}_{1}$ values for material attractiveness as listed in Table 2, showing that the ${ }^{233} \mathrm{U}$ in the AHWR is at least as attractive as reactor grade plutonium, while the uranium discharged from AHWR-LEU has attractiveness similar to LEU.

- $\quad$ The AHWR fuel cluster is significantly larger and heavier than a CANDU fuel bundle. The fueling and re-fueling operations and the fuel transfers are much more complicated due to the remote assembly and disassembly of the shield sections to the fuel cluster, and the overall length of $10.5 \mathrm{~m}$ for the shields/fuel assembly.

- $\quad$ The AHWR refueling interval is relatively infrequent, 113 fuel channels per year, or about 1 fuel cluster every three days, as compared to the typical handling averaging 6 much shorter CANDU fuel bundles per day. As a result, the AHWR refueling machine may be more readily available for refueling operations supporting short-time irradiations or other non-standard operations.

- $\quad$ The capability to detect non-standard operation in support of safeguards implementation is unknown. It is noted that the low power generation per cluster may make it easier to irradiate non-standard materials since the disturbance to the core is low, likely increasing the potential for misuse.

- $\quad$ Spent fuel clusters would most likely be stored intact prior to further processing.

- $\quad$ At the time of processing spent AHWR fuel, disassembly of the fuel cluster separates the $\mathrm{PuO}_{2} / \mathrm{ThO}_{2}$ fuel pins from the $\mathrm{UO}_{2} / \mathrm{ThO}_{2}$ fuel pins for separate processing. The plutonium content in the spent $\mathrm{PuO}_{2} / \mathrm{ThO}_{2}$ fuel is less than $0.7 \%$, lower than the $1 \%$ or so that is typical of spent LWR fuel. However, the plutonium is also of low attractiveness, with less than $20 \%$ fissile content as listed in Table 3 . The quantity of plutonium in the spent $\mathrm{UO}_{2} / \mathrm{ThO}_{2}$ fuel is insignificant, although it would be of higher attractiveness. However, the uranium recovered from processing $\mathrm{UO}_{2} / \mathrm{ThO}_{2}$ fuel is highly attractive, as noted above.

- $\quad$ For processing AHWR-LEU fuel, all of the fuel is enriched uranium so no segregation of the fuel pins is required. The plutonium is attractive based on $\mathrm{FOM}_{1}$, and the quantity is likely to be comparable to that in spent LWR fuel given the use of enriched uranium in AHWR-LEU which is greater than $80 \%{ }^{238} \mathrm{U}$. Any ${ }^{233} \mathrm{U}$ in the spent AHWR-LEU fuel is with large amounts of ${ }^{238} \mathrm{U}$. 


\subsection{Possible Proliferation-Related Strengths}

From this initial review, positive nonproliferation attributes for the two reactors are difficult to identify clearly, at least in comparison to existing LWR technology. The AHWR produces very little plutonium since there is no ${ }^{238} \mathrm{U}$ in the fuel and has a low percentage of ${ }^{239} \mathrm{Pu}$ remaining in the spent fuel from the initial plutonium loading. It effectively burns the plutonium in the $\mathrm{PuO}_{2} / \mathrm{ThO}_{2}$ fuels used to drive the thorium to produce ${ }^{233} \mathrm{U}$. At the same time, it is very important to recognize that this positive attribute with respect to plutonium comes along with the negative attributes of the highly attractive ${ }^{233} \mathrm{U}$ in the spent fuel, so that in effect, a trade has been made, and when all is considered, it appears that any benefit from the greatly reduced plutonium content is offset by the production of highly attractive uranium. However, the presence of ${ }^{232} \mathrm{U}$ may potentially complicate attempts at proliferation due to the emission of $2.6 \mathrm{MeV}$ gamma radiation making the uranium difficult to shield and easy to detect.

The AHWR-LEU, as the name suggests, uses low-enriched uranium fuel and produces plutonium from ${ }^{238} \mathrm{U}$, just as in an LWR. The plutonium in the used fuel has 4 to $10 \%{ }^{238} \mathrm{Pu}$ and 41 to $54 \%{ }^{239} \mathrm{Pu}$, similar in attractiveness to reactor grade plutonium from an LWR, but with a quantity that is about $10 \%$ lower than in a PWR. Again, this is only a small change from existing LWR technology.

\subsection{Possible Proliferation-Related Weaknesses}

It is also difficult to clearly identify specific negative nonproliferation aspects for these two reactors in comparison to existing LWR technology. Both the AHWR and AHWR-LEU use heavy water, a material of concern with regards to proliferation since use in reactors will allow production of weapons-grade plutonium from natural uranium. Given the high thermal crosssection of ${ }^{232} \mathrm{Th}$, use of thorium in heavy-water moderated reactors will also be effective at producing ${ }^{233} \mathrm{U}$. Whether the use of heavy-water is a negative nonproliferation attribute is not clear. As with other reactors, it is possible to misuse the AHWR and AHWR-LEU for efficient ${ }^{233} \mathrm{U}$ or plutonium production.

The intent is to process spent AHWR fuel using a three-stream separation technique for the uranium, plutonium and thorium, which will create opportunities for diversion of nuclear material, as with any processing approach. Any country with the full system may also have gained technical knowledge and experience that would be useful for taking a plutonium or ${ }^{233} \mathrm{U}$ path to weapons production.

The AHWR will use an average of 3.0-3.5 wt\% plutonium in the fresh fuel, requiring approximately $500 \mathrm{~kg}$ of $\mathrm{PuO}_{2} / \mathrm{ThO}_{2}$ fuel annually and the fresh fuel has a $\mathrm{FOM}_{1}$ of 2.60. Hence, according to the IAEA definitions, the fresh fuel is "unirradiated direct-use material" with a 1-month detection timeliness period for the plutonium. Also, there are substantial quantities of potentially weapons-useable ${ }^{233} \mathrm{U}$ in the spent fuel. Although the developers of the AHWR claim the presence of ${ }^{232} \mathrm{U}$ as a sufficient deterrent, Tables 2 and 3 suggest that even the lowest grade ${ }^{233} \mathrm{U}$ from the AHWR is a fairly attractive material and will still be weapons-usable. The fresh fuel of the AHWR-LEU contains $19.75 \%$ enriched ${ }^{235} \mathrm{U}$ (HEU is uranium enriched to greater than or equal to $20 \%{ }^{235} \mathrm{U}$ ), whereas the more commonly used LWR fuel is 3 to $5 \%$ 
enriched in ${ }^{235} \mathrm{U}$. Because the export reactor will not have reprocessing and fuel fabrication facilities, both fresh and spent fuel shipments across international borders will frequently occur. International transportation of $19.75 \%{ }^{235} \mathrm{U}$ LEU may pose physical protection risks for the AHWR-LEU fresh fuel since it may be an attractive theft target. Depending on where the uranium enrichment facilities are, any shipments of $\mathrm{UF}_{6}$ to the fuel fabrication facility would also be attractive targets.

Additionally, the AHWR-LEU will produce plutonium, albeit in smaller quantities with lower ${ }^{239} \mathrm{Pu}$ content relative to a PWR. However, the isotopic composition of the plutonium is variable since burnup is easily adjustable in a reactor that is capable of on-line refueling, such as the AHWR-LEU. It is possible, although not ideal, to use the plutonium produced in the AHWRLEU in a weapon, once again representing a proliferation risk in a variety of settings as seen in the FOM tabulations in Table 2. 


\subsection{REFERENCES}

1. R. K. Sinha and A. Kakodkar, Design and Development of the AHWR - the Indian Thorium Fuelled Innovative Nuclear Reactor, Nuclear Engineering and Design, 236 (2006) 683-700.

2. P.D. Krishnani, Study of Th-LEU Fuel in AHWR to Enhance Proliferation Resistance Characteristics, TM on Preparation of a NE Series Report, IAEA, Vienna, Austria, June 8-11, 2010. 


\section{APPENDIX A}

\section{CALCULATIONS OF FOM AND FOM $_{2}$ FOR MATERIAL ATTRACTIVENESS}

This appendix presents a detailed analysis of the attractiveness of the materials associated with the Indian AHWR. The analysis began by examining the material associated with the calandria tube design, shown in Figure A1, which is a simplified representation of the actual design shown in Figure 5. For details of the design used in this analysis, the reader is referred to References [A1] and [A2].

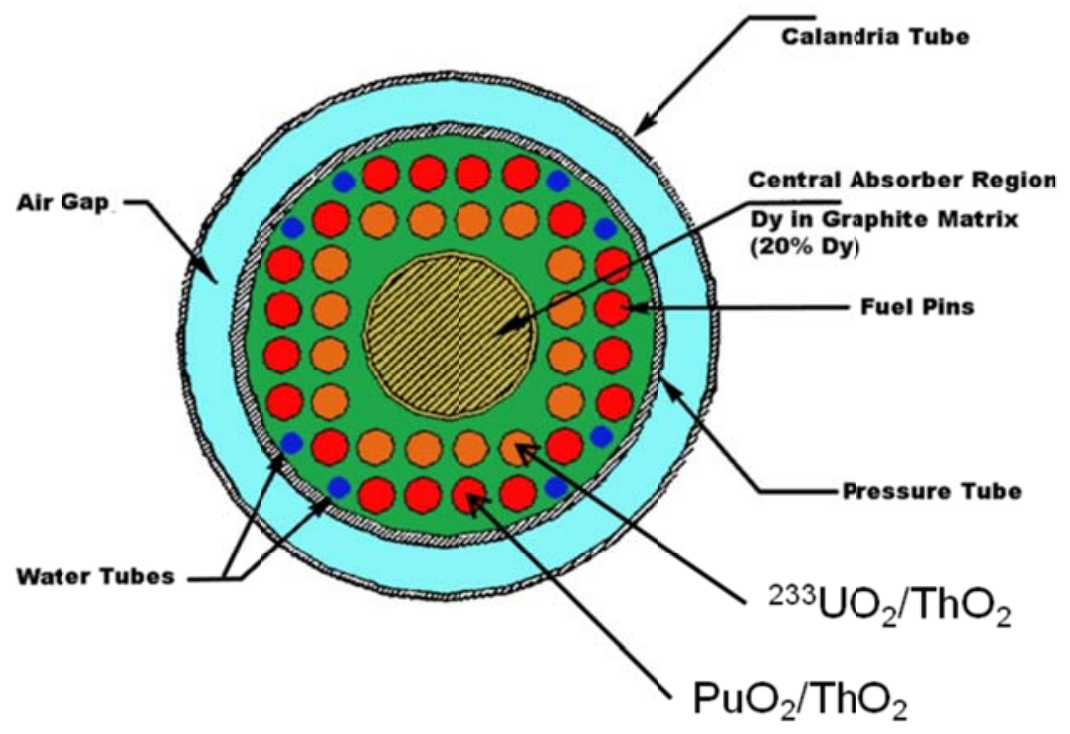

Figure A1. The Basic Calandria Tube Used in the Analysis of Material Attractiveness.

The isotopic compositions of the used fuel for calculating $\mathrm{FOM}_{1}$ and $\mathrm{FOM}_{2}$ were determined using SCALE [A3]. The physical properties of the materials for the FOM calculations were determined using MCNP-X [A4]. For an object identified as the source of material used in a nuclear explosive device, the following formula evaluates material attractiveness for most adversaries [A5],

$$
F O M_{1}=1-\log _{10}\left(\frac{M}{800}+\frac{M h}{4500}+\frac{N}{10}\left[\frac{D}{500}\right]^{\frac{1}{\log _{10} 2}}\right)
$$

where $M$ is the bare critical mass of the metal in $\mathrm{kg}, h$ is the heat content in $\mathrm{W} / \mathrm{kg}, N$ is the mass of the source object, and $D$ is the dose rate of $N$ evaluated at $1 \mathrm{~m}$ from the surface in $\mathrm{rad} / \mathrm{h}$. If a specific object is unknown, then Equation 2 evaluates material attractiveness,

$$
F O M_{1}=1-\log _{10}\left(\frac{M}{800}+\frac{M h}{4500}+\frac{M}{50}\left[\frac{D}{500}\right]^{\frac{1}{\log _{10} 2}}\right)
$$


where $D$ is the dose rate of $0.2 \cdot M$ evaluated at $1 \mathrm{~m}$ from the surface in $\mathrm{rad} / \mathrm{h}$.

For nations that would desire devices with a reliably high yield, pre-initiation is an issue. Materials with a high spontaneous neutron generation rate reduce the material attractiveness. In such cases, the variant $\mathrm{FOM}_{2}$ also evaluates material attractiveness,

$$
F O M_{2}=1-\log _{10}\left(\frac{M}{800}+\frac{M h}{4500}+\frac{M S}{6.8(10)^{6}}+\frac{N}{10}\left[\frac{D}{500}\right]^{\frac{1}{\log _{10} 2}}\right)
$$

where $S$ is the spontaneous-fission neutron production rate in $\mathrm{n} / \mathrm{s} / \mathrm{kg}$. Again, if a specific object is unknown, then $\mathrm{FOM}_{2}$ is

$$
F O M_{2}=1-\log _{10}\left(\frac{M}{800}+\frac{M h}{4500}+\frac{M S}{6.8(10)^{6}}+\frac{M}{50}\left[\frac{D}{500}\right]^{\frac{1}{\log _{10} 2}}\right)
$$

In all cases, a FOM, either $\mathrm{FOM}_{1}$ or $\mathrm{FOM}_{2}$, greater than 1 indicates that the material is attractive to a potential adversary. If the FOM is also greater than 2, then the material is very attractive to a potential adversary, e.g., a preferred material. If the FOM is less than 1, then the material is generally unattractive to a potential adversary.

Figure A2 shows the material attractiveness results using Equations (2) and (4). The FOM result represents the maximum attractiveness for a scenario in which an adversary acquires material after reprocessing of the used fuel and safeguards assessments should use this value.
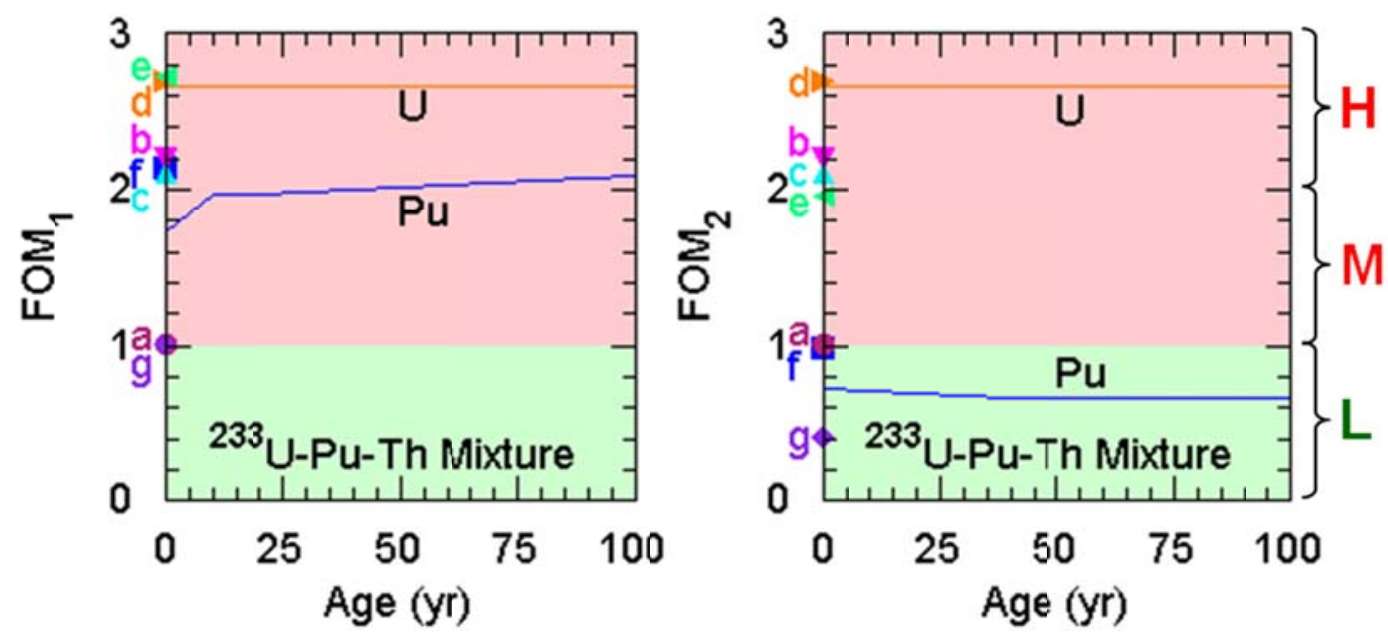

Figure A2. FOM Fnd $_{1} \mathrm{FOM}_{2}$ Versus Time after Discharge for a Generic Source Object (i.e., Eqns. (2) and (4)). 
The letters $\mathrm{H}, \mathrm{M}$, and $\mathrm{L}$ denote high, medium, and low attractiveness, respectively, as listed in Table A1. Included for reference are the following data points: a - LEU (20\%), b - HEU (93\%), c - ${ }^{237} \mathrm{~Np}, \mathrm{~d}-{ }^{233} \mathrm{U}\left(10 \mathrm{ppm}{ }^{232} \mathrm{U}\right), \mathrm{e}-\mathrm{WG}-\mathrm{Pu}, \mathrm{f}$ - RG-Pu (45 MWd/kg and cooled 10 years), and $\mathrm{g}-{ }^{238} \mathrm{Pu} /{ }^{239} \mathrm{Pu}(80: 20)$.

Some adversaries might acquire their material by stealing used fuel and reprocessing the used fuel themselves. The smallest unit of used fuel for the AHWR is a fuel cluster (similar in concept to an LWR assembly). Because a fuel cluster contains fission products and other radioactive elements in addition to plutonium or uranium, its dose poses a significant obstacle to the adversary. Figure A3 shows the dose from a fuel cluster. Based on the traditional dose rate criteria of $100 \mathrm{R} / \mathrm{h}$ at $1 \mathrm{~m}$, a used fuel cluster would no longer be self-protecting after 105 years of aging.

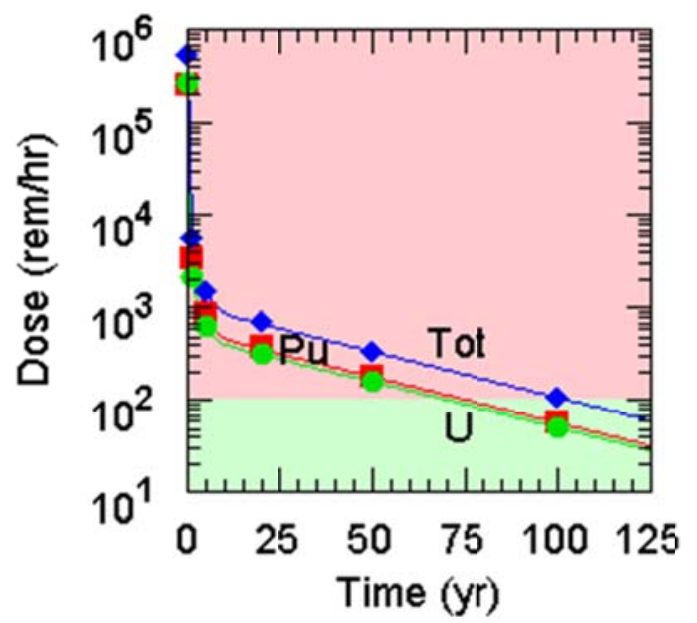

Figure A3. The Dose of a Used Fuel Cluster versus Time.

Having identified a specific source object, Figure A4 gives the attractiveness of the material within a fuel cluster. These $\mathrm{FOM}_{1}$ results represent the maximum attractiveness for a scenario in which an adversary acquires a used fuel cluster and does his own reprocessing of the used fuel. As can be seen in the figures, material attractiveness of the recovered materials increases with time after discharge, being greater than 1.0 about 38 years after discharge.
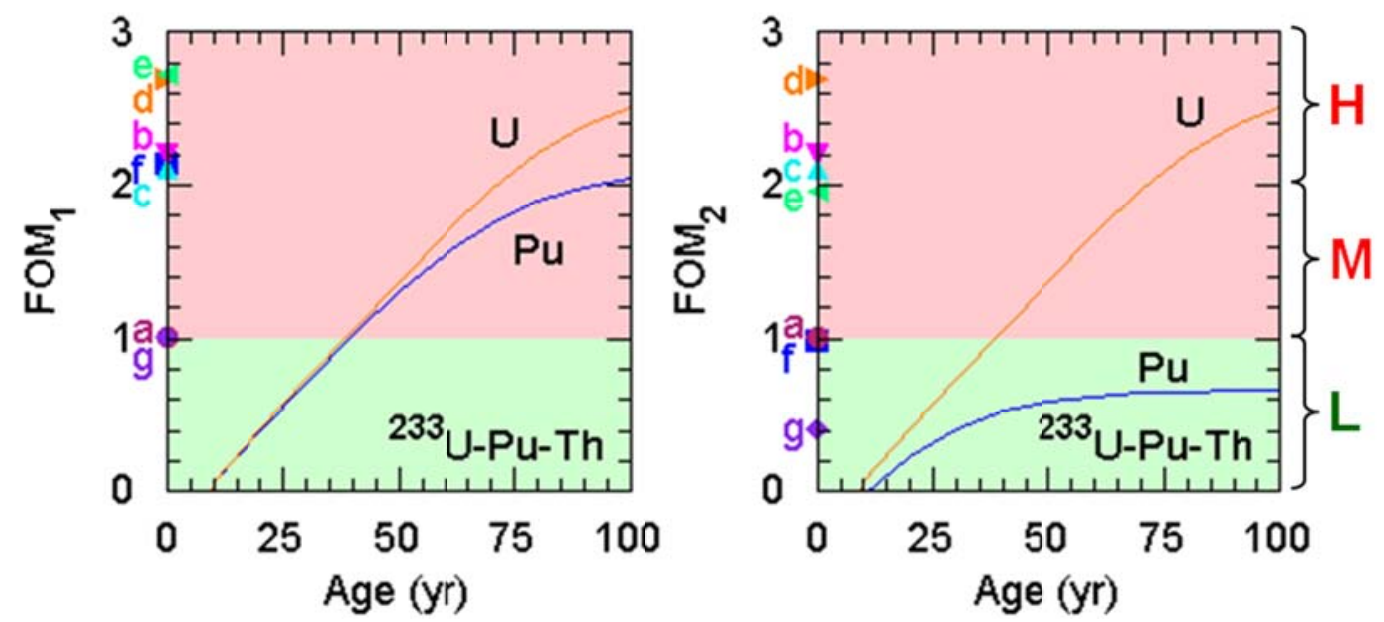

Figure A4. FOM 1 and FOM 2 Versus Time After Discharge (i.e., Eqns. (1) and (3)). 
The letters $\mathrm{H}, \mathrm{M}$, and $\mathrm{L}$ denote high, medium, and low attractiveness, respectively (see Table A1Error! Reference source not found.). Included for reference are the following data points: a LEU (20\%), b - HEU (93\%), c - ${ }^{237} \mathrm{~Np}, \mathrm{~d}-{ }^{233} \mathrm{U}$ (10 ppm $\left.{ }^{232} \mathrm{U}\right)$, e - WG-Pu, f - RG-Pu (45 $\mathrm{MWd} / \mathrm{kg}$ and cooled 10 years), and $\mathrm{g}-{ }^{238} \mathrm{Pu} /{ }^{239} \mathrm{Pu}(80: 20)$.

Table A1. The Meaning of FOM When Applied to Metals or Alloys

\begin{tabular}{|c|c|c|c|}
\hline FOM & Weapons Utility & Attractiveness & $\begin{array}{c}\text { Attractiveness } \\
\text { Level }^{3}\end{array}$ \\
\hline$>2$ & Preferred & High & $\sim \mathrm{B}$ \\
$1-2$ & Attractive & Medium & $\sim \mathrm{C}$ \\
$0-1$ & Unattractive & Low & $\sim \mathrm{D}$ \\
$<0$ & Unattractive & Very Low & $\sim \mathrm{E}$ \\
\hline
\end{tabular}




\section{REFERENCES}

A1. B. W. Sleaford, B. A. Collins, B. B. Ebbinghaus, C. G. Bathke, A. W. Prichard, R. K. Wallace, B. W. Smith, K. R. Hase, K. S. Bradley, M. Robel, G. D. Jarvinen, J. R. Ireland, and M. W. Johnson, "Nuclear Material Attractiveness: An Assessment of Material from PHWR'S in a Closed Thorium Fuel Cycle,” Proc. of ENC 2010, May 30 - June 2, 2010, Barcelona, Spain.

A2. C. G. Bathke, B. W. Sleaford, B. B.Ebbinghaus, B. A. Collins, R. K. Wallace, K. R. Hase, K. S. Bradley, A. W. Prichard, and B. W. Smith, "An Assessment of the Attractiveness of Material Associated with Thorium/Uranium and Uranium Closed Fuel Cycles from a Safeguards Perspective,” Proc. of INMM 51st Annual Meeting, July 1115, 2010, Baltimore, MD (also Los Alamos National Laboratory document LA-UR-1003899).

A3. "SCALE: A Modular Code System for Performing Standardized Computer Analyses for Licensing Evaluation - Version 6,” Oak Ridge National Laboratory Report ORNL/TM2005/39 (2009).

A4. Denise B. Pelowitz, ed., “MCNPX User’s Manual, Version 2.6.0,” Los Alamos National Laboratory report, LA-CP-07-1473 (April 2008).

A5. Charles G. Bathke, Bartley B.Ebbinghaus, Brad W. Sleaford, Richard K. Wallace, Brian A. Collins, Kevin R. Hase, Martin Robel, Gordon D. Jarvinen, Keith S. Bradley, John R. Ireland, M. W. Johnson, Andrew W. Prichard, and Brian W. Smith, “An Assessment of the Attractiveness of Material Associated with a MOX Fuel Cycle from a Safeguards Perspective,” Proc. of INMM 50th Annual Meeting, July 12-16, 2009, Tucson, Ariz. (also Los Alamos National Laboratory document LA-UR-09-03637). 